\title{
On the Teachability of Figurative Language: Teachers' Perceptions of the Role of Metaphor in English Language Teaching in Chile
}

\section{La enseñabilidad del lenguaje metafórico: percepciones de docentes sobre el rol de la metáfora en la enseñanza del inglés en Chile}

\author{
Leonardo Veliz ${ }^{1}$ \\ Scott Smith ${ }^{2}$
}

\begin{abstract}
Citation/ Para citar este Artículo: Veliz, L., \& Smith, S. (2021). On the Teachability of Figurative Language: Teachers' Perceptions of the Role of Metaphor in English Language teaching in Chile. Colomb. Appl. Linguistic. J., 23(2), pp. 141-154.
\end{abstract}

Received: 08-Oct.-2020 / Accepted: 15-Jul.-2021

DOI: https://doi.org/10.14483/22487085.17071

\begin{abstract}
This paper reports on a qualitative study that examined the perceptions of English teachers towards the 'teachability' of metaphorical language in Chilean EFL classrooms. The study aimed at gaining a better understanding of teachers' perceptions of the role of metaphor in the English language classroom. A group of six in-service English teachers participated in this qualitative study. Data were gathered through semi-structured interviews, which addressed three broad dimensions: (i) the views and definitions of metaphor; (ii) the teachability of metaphorically used language; and (iii) preparedness to teach metaphor. The data were thoroughly coded and analyzed thematically. The results revealed that, despite an apparently heightened awareness of the presence and role of metaphor in culture, this did not permeate the participants' teaching practices, thus calling for more explicit preparation in teacher education programs and radical changes to the 'educational culture' that is still imbued with dominant neoliberal ways of doing and thinking.
\end{abstract}

Keywords: metaphor and culture, metaphor in Chile, metaphor in EFL, neoliberalism and education, teaching metaphor

\section{Resumen}

El presente trabajo da cuenta de un estudio cualitativo que examinó las percepciones de profesores de inglés sobre la 'enseñabilidad' del lenguaje metafórico en aulas chilenas de EFL. El estudio tuvo como objetivo obtener una mejor comprensión de las percepciones de los profesores sobre el rol de la metáfora en las aulas de inglés. Un grupo de seis profesores activos de inglés participaron en este estudio cualitativo. La recopilación de datos se realizó a través de entrevistas semiestructuradas, las que abordaron tres dimensiones generales: (i) percepciones y definiciones de metáfora; (ii) enseñabilidad del lenguaje de uso metafórico; y (iii) preparación para enseñar metáfora. Los datos fueron rigurosamente codificados y analizados temáticamente. Los resultados revelaron que, a pesar de una aparentemente alta conciencia del rol y la presencia de la metáfora en la cultura, esta no logra impregnarse en las

1 Dr. Leonardo Veliz. Excelsia College, Australia. ORCID (D): https://orcid.org/0000-0003-2489-7484. leonardo.veliz@excelsia.edu.au

2 Dr. Scott Smith. Excelsia College, Australia. ORCID iD: https://orcid.org/0000-0001-5424-0497. scott.smith@excelsia.edu.au 
practicas pedagógicas de los profesores, lo que llama a una preparación pedagógica explicita en los programas de formación de profesores para la enseñanza de la metáfora, al igual que cambios radicales en la 'cultura educacional' que está todavía impregnada por aspectos del pensamiento y actuar neoliberal.

Palabras clave: metáfora y cultura, metáfora en Chile, metáfora en el inglés como lengua extranjera, neoliberalismo y educación, enseñanza de metáforas

\section{Introduction}

Teaching and learning another language require mastery of a variety of linguistic, social, and cultural skills and competencies. There are, however, a number of complications and challenges that learners have to face when learning a language in a Target-Language-Removed contexts (Graves, 2008), of which Chile is an example. In these contexts, English as a foreign language (EFL) learners have limited opportunities for using the language in authentic situations and are often taught through teaching approaches which reinforce rote-learning with a particularly strong focus on forms (Laufer, 2006) and generally exclude attention to the cognitive, social, and cultural dimension of figurative language (Littlemore, 2009).

Figurative language, including all its various forms of figure of speech (e.g. metaphor, simile, metonymy, irony, sarcasm, etc.), has attracted a great deal of attention amongst scholars in literary studies, the philosophy of language, psychology, semantics, and pragmatics. A more contemporary perspective on metaphor has been embraced by the relatively new field of cognitive linguistics (CL). CL, according to Tyler (2012), offers "a different understanding of the nature and organization of language, one which is more accurate, explanatory and more complete than the traditional view" (p. 4). One of the basic tenets of CL is its primary focus on the social nature of language, along with the unique ways in which humans experience and interact with the world. This, unlike the traditional thinking around metaphor, suggests that our primary sensorimotor experiences in/with the world play a fundamental role in framing our conceptual structures, which, later on, as language develops, become manifest in our use of language.

In recent years, there has been a strong impetus for exploring the benefits of metaphor to the development of second language learners' grammatical, lexical, and, above all, communicative skills. Littlemore (2001, 2010) and Danesi (1986), for instance, have argued that 'metaphoric competence', an area which has unfortunately not been explored in its own right, is an essential component of communicative competence, which, according to Littlemore, 2010 comprises grammatical, sociolinguistic, discourse, and strategic competences. To this, Littlemore, 2010 adds that "effective communication in a second language involves the ability to use metaphor" (p. 461). She later argues that the ability to use metaphor effectively is due to a gap in knowledge, rather than variations in cognitive processing (Littlemore, 2010), which, from a pedagogical perspective, can be addressed through explicit instruction (Gutiérrez-Pérez, 2016, p. 4). This, as pointed out by e.g. Kalyuga and Kalyuga, 2008, requires the inclusion of a conceptual awareness method in language syllabi aimed at developing proficiency in L2. Conceptual (metaphor) awareness procedures have been systematically used by several researchers to deepen students' understanding of vocabulary (e.g. Kalyuga and Kalyuga, 2008), their understanding of literature (e.g. Picken, 2005), vocabulary retention (e.g. Boers, 2000), and comprehension of idiomatic expressions (e.g. Shan-feng, 2007). An effective implementation of conceptual (metaphor) awareness procedures requires, according to Shanfeng (2007), addressing the various domains of a metaphor through explicit instruction. Given the apparently insufficient emphasis on integrating the teaching and learning of metaphor in EFL in Chile, it could be pointed out that teachers and educators require the adequate pedagogical preparation to deliver effective pedagogy in this domain. This is, to the best of our knowledge, an unexplored territory in the Chilean context. Motivated by what may be a significant gap in this realm of research in Chile, this study seeks to address the following two research questions: 
1. What are Chilean EFL teachers' views and understandings of metaphor?

2. What are English language teachers' perceived challenges in implementing a more strategic pedagogical approach to the teaching of metaphor in EFL classrooms?

\section{Theoretical Framework}

The theoretical lens through which this research is conducted lies at the heart of metaphor studies, particularly what has come to be known as 'conceptual metaphor theory'. Many of the recent developments in metaphor research are theoretically grounded in the works of Lakoff and Johnson (1980). They shifted traditional thinking and theorizing about metaphor to a more comprehensive view that has positioned the concept of metaphor right at the interface of language and cognition. Lakoff and Johnson (1980) put forward the idea that a metaphor is a conceptual mapping between two domains. By this, they mean, first and foremost, that metaphor is not just a matter of language, but of cognition as well. Secondly, the cross-mapping of domains where, for instance, one is more concrete than the other, is a reflection of how humans experience and interact with the world. These basic premises have framed much of the increasingly large volume of scholarly work in this field over the last two decades.

Central to much of the discussion on the interplay between humans' experiences and interactions with the world and metaphor is the question pertaining to linguistic relativity and universality (Kövecses, 2005). The question of whether language influences thought, or thought influences language, which has been generally associated with the so-called 'Sapir-Whorf hypothesis', has generated some significant discussion as to whether metaphor - and therefore the way we reason and speak metaphorically - is universally-grounded in our most basic sensorimotor physical experiences with and in the world, or whether there is a degree of variation across cultures. Empirical research has provided supporting evidence for both sides. Dirven and Verspoor (2004) argue that universalism, understood as the most traditional stance on human thought, can be defined as a view wherein "all people all over the world basically think in the same way" (p. 131). As simplistic as it may sound, philosophers such as Pascal, Descartes, and Arnauld have indeed held the view that a set of universal concepts exists, to which they have referred as 'simple ideas' (Dirven and Verspoor, 2004), while cognitive linguists have called them 'semantic primes' (Peeters, 2006; Goddard and Wierzbicka, 2007). Examples of these can be, for instance, life, death, temporal concepts, spatial concepts, amongst others, all of which have a universal nature. Nevertheless, there are several weaknesses associated with the idea of semantic primes. First, a single semantic prime can, more often than not, be expressed by different words in different contexts, and in different cultures. Secondly, there is a limited number of semantic primes which does not account for all 'atoms of meaning' which can be expressed by different people across cultures (Dirven and Verspoor, 2004). Thirdly, according to Dirven and Verspoor (2004) "the vast majority of words in any given language have complex and rather language-specific meanings" (p. 134), which leads us to the conclusion that, irrespective of the universality of such general linguistic categories as semantic primes, different phenomena are conceptualized and metaphorically construed different across different cultures. This is the premise upon which the culture specificity (Fan and Tan, 2015) view of metaphor is grounded.

\section{The teachability of metaphor}

From these perspectives of metaphor as being universal or culturally bound emerge several questions about what kinds of metaphor should be taught; how universal metaphor, especially those relating to semantic primes, should be dealt with pedagogically; what kinds of culture-specific metaphors are most relevant in a foreign language context; and how teachers can be effectively trained and prepared to deliver a metaphor approach. However, despite the increasing volume of research in metaphor studies, there is no easy answer to these questions, given the insufficient amount of research that has been conducted on 'metaphor' pedagogies, that is, what pedagogical approaches, 
strategies, methodologies, and techniques can be implemented for the successful teaching of metaphor. Littlemore and Low (2006) argue that, although many (e.g. Dirven, 1985; Hoang, 2014; Littlemore, 2005) have argued in favor of metaphor research as having important implications for second language teaching and learning, "it has taken a long time for metaphor to make significant headway into mainstream pedagogical practice and the design of teaching materials" (p. 268). The precise reasons as to why we seem to be facing a dissociation between the significant volume of scholarly work on metaphor studies, as well as the increasingly limited research (at least in Chile and Latin America) on the pedagogical dimensions of metaphor, are truly unknown. Perhaps, the wide popularity of the premises and uses of metaphor research within the realm of cognitive linguistics have not yet impacted teaching and scholarship in South America. Littlemore and Low (2006) point out that one reason can be the highly conventionalized nature of language items which have been used to exemplify cases of metaphor in English, most of which have already been used and taught (conventionally) as part of stand-alone English vocabulary items.

However, some of the various studies which have looked at the systematicity of metaphorical language have provided great insights into language pedagogy. For instance, Véliz (2016,2018) examined the benefits of deploying a metaphor-awareness approach in the teaching of polysemous and metaphorically used words. Results revealed that explicit instruction specifically aimed at developing EFL learners' awareness enhances not only their lexical repertoire but also their abstract thinking and capacity to better comprehend mapping between abstract and concrete concepts. The benefits of metaphor awareness have been explored by several researchers in a variety of second language learning contexts (e.g. Deignan et al., 1997; Hsiao and Leong, 2018; Picken, 2005). For example, Picken (2005) investigated the ways in which a metaphorawareness raising approach could enhance Japanese English language learners' capacity to make sense of linguistic metaphors in literature. Deignan et al. (1997) conducted a cross-linguistic study which reported on a translation exercise undertaken by a group of advanced Polish learners of English, who, through a process of metaphor awareness, were able to develop a deeper understanding of metaphor in L1 and L2.

Some of the research which has indeed looked at English language pedagogy in Chile through the lens of metaphor studies has paid specific attention to language learners' metaphorical conceptualizations of language learning (Farías and Véliz, 2016), as well as the identity of pre-service teachers (Farías and Véliz, 2019). Although these studies have made a significant contribution to our understanding of how learners metaphorically conceptualize the language learning process, and how pre-service teachers metaphorically construe the process of (teacher) identity construction and negotiation, they have not shed any light on the pedagogical treatment of metaphor in a classroom context, which is what this study seeks to investigate.

\section{Methodology}

The methodological approach underpinning this study responds to the ontological relativistic and constructivist claim in qualitative research that multiple, diverse, and often seemingly contradictory but equally valid accounts of a phenomenon contribute to the construction and understanding of a particular reality (Johnson and Onwuegbuzie, 2004). 'The reality' under scrutiny in this research is English language teachers' perceptions of the teachability of metaphorical language in Chilean classrooms. In order to uncover these perceptions, a semi-structured interview was used with a set of open-ended questions which broadly addressed three broad dimensions: (i) the views and definitions of metaphor; (ii) the teachability of metaphorically used language; and (iii) the preparedness to teach metaphor. The interviews were conducted via Zoom video conferences and were set up for automatic recording for later transcription and analysis.

The main reason for using open-ended questions in the survey was to enrich the quality of the data, giving voice to teachers (Wang et al., 2013). When interviewees are given some freedom to elaborate, follow tangents of thought, pose questions and perhaps self-correct, they can provide 
a richer, more meaningful account of their thoughts and experiences (Newton et al., 1999).

\section{Data analysis}

The interview data were transcribed, coded, and thematically analyzed. Braun and Clarke (2006) define thematic analysis as a "method for identifying, analyzing, and reporting patterns (themes) within data" (p. 79). The salience, significance, and 'keyness' of a theme is not dependent on quantifiable measures (Braun and Clarke, 2006), but rather on whether it captures the thrust of the ideas that relate to the research questions of the study. The analysis was led by an inductive approach wherein the patterns, themes, and categories have emerged out of the data rather than being imposed or pre-determined a priori (Srivastava and Hopwood, 2009). Three broad emerging themes were identified in the data. The first was labelled Metaphor in language and culture as several of the features that emerged in the coding process are related to cultural values, different perspectives, meanings in society, etc. The second theme was named In need of preparation which captured participants' lack of pedagogical preparation to teach metaphor in a foreign language context. The last theme, A different teaching culture, a different focus, encapsulated participants' views of their school culture, challenges, and limitations, which hinder the implementation of a (communicative) metaphor approach, as well as reactions against a pervasively strong culture of compliance.

\section{Participants, recruitment, and ethical considerations}

A group of six in-service EFL teachers participated in this qualitative study. Some demographic data gathered from participants show that they are all qualified to teach EFL in Chile, as they hold a Bachelor's degree in English Language Teaching (ELT). All the participants obtained their English teaching degrees in Chile. Four earned their degrees at private universities, whereas the other two at public (government-funded) universities. At the time of the interviews for the present study, all participants had full-time teaching positions in private schools in Santiago de Chile. They are all currently undertaking a Master's degree in Teaching English as a Foreign Language (TEFL) at a Chilean university in Santiago. All participants have been teaching EFL for at least five years in various school contexts. They are all currently fulltime employees in public schools, three of which are deemed, according to the 'Agencia de Calidad de la Educación' (2020) [Education Quality Agency], socially-disadvantaged schools.

A group of 11 participants were contacted by email, where an invitation was made to take part in the study. With a brief description of the study, the email requested that an expression of interest be sent to the researchers if they wished to participate. Over the course of three and a half weeks, six responses to the email came through, all of which expressed an interest to be part of the study.

This was followed by more frequent email communication with the participants, in which specific details of the study were shared, consent forms were sent, and convenient dates and times for interviews were discussed.

\section{Context of study}

A long-standing idealized goal to become a bilingual country has long been embraced in Chilean society. Through a wide range of government initiatives such as 'Inglés Abre Puertas [English Opens Doors Program], 'Semestre en el Extranjero' [Semester abroad], Chile has made serious attempts to strengthen English teacher education programs in order to better prepare preservice English language teachers to exercise their profession. Upon successful completion of their degrees, and once fully immersed in the workforce, teachers are, however, faced with a number of pedagogical, social, and cultural challenges that impede the effective implementation of 'meaningful' classroom practice facilitative of authentic learning. Some of these impediments include the numerous notoriously-known issues of overpopulated classrooms, the scarcity of teaching resources, children with behavioral problems, the vulnerability of a large student population in socially-disadvantaged schools, students with low levels of motivation to 
learn a foreign language, and EFL teachers who are disappointedly forced to orchestrate much of their teaching in and through the students' first language. What adds a further complication to this is the level of educational accountability which, alongside its benefits and relevance to the measurement of teacher and school effectiveness (Barber and Mourshed, 2018), raises critical questions about its detrimental effects on how it has narrowed curricula, reduced local control, deskilled teachers, and resulted in the overall deprofessionalization of teaching practices (Fernández, 2018). In Chile, as well as in most Latin American countries, educational accountability policies were fully embraced through the adoption of "an orthodox form of neo-conservative economics" (Avalos, 2004, p. 70) under the dictatorship of Augusto Pinochet (1973-1990), which severely impacted all spheres of society, including education. Chile's neoliberal transformation manifested itself not only in economic growth through direct foreign investment, but also in the pervasive adoption of policies which established and promoted the marketization/commoditization of education. In the education arena, the inception of these policies became particularly reflected in the rapid creation and establishment of private universities, which began to fiercely market and promote a wide range of degree programs in a variety of disciplinary areas. Teaching degrees, including English language teacher education programs, were no exception. According to Peters (2012), the neoliberal agenda in education has infused notions of "commercialisation, corporatisation and incremental privatisation" (p. 135), which, in Aviles and Simons' (2013) view, increase teachers' accountability and performativity pressures, limit their teaching and pedagogical capabilities, and, according to Doecke et al. (2004), have fostered a discourse of 'knowledge reproduction' rather than 'knowledge production'. As a consequence, this has impacted the ways that "[metaphorical] language and literacy are treated as a set of basic skills that can somehow be conceptualised apart from the contexts and practices in which they are applied" (Doecke et al., 2004, p. 30).

Further severe consequences of this neoliberal agenda were seen in the centralization of educational authority, the weakening of power of teacher unions and school boards, and the increase in standardsbased accountability and testing (Arsen and Masen, 2013). This is the nature of the socio-political and socio-educational context within which the present study is situated.

Although Chile currently enjoys the 'privileges' of a democratic society that won the battle against a military government, many of the educational and pedagogical practices are still highly influenced and framed by not only the neo-conservative policies embraced during dictatorship, but also, and most importantly, by the rigid ideologies of hierarchy, power imbalance, and inequity imposed and celebrated by a military-governed society at the time.

\section{Findings}

This section reports on the qualitative findings gleaned from an analysis of the participants' interview data. The themes that emerged from the analysis are reported and discussed in the order of the formulated research questions.

Teachers were asked to share their views on metaphor: what they think it is and how it can be defined. Despite a certain level of ambivalence observed amongst responses, most participants expressed similar ideas on how they view metaphor. Of particular interest was their discovery of the interface between language and culture they observed when defining metaphor.

I really think metaphors are cultural tools, and ways of thinking that we can use to pass on our cultural values and traditions so we should all know about them. Every time I think about metaphors I think of Spanish idioms (Peter).

Peter's first observation about metaphor touches on its cultural dimension. There was no mention about metaphor being related to poetry, literary studies, or philosophy, as briefly expressed by another participant. Metaphor, for Peter, seems to be a conduit of cultural values and traditions which, as such, should be known by everyone. Understanding metaphor in relation to culture leads us to unpack the pervasive nature of metaphorical 
language as a representation and manifestation of our individual cultural experiences and interactions with the world (Lakoff and Johnson, 1980). This was tacitly mentioned by another participant:

I always think about the language I use to talk about certain things and the language my grandma uses for the same things. Sometimes it's like we see the world from different perspectives and sometimes think differently, or that we are from different cultures. This is what come to mind when I think about metaphor, and metaphors in my language (Sharon).

A rather salient observation made by Sharon points to the different perspectives from which she and her grandmother come to an appreciation and understanding of the world. This is precisely what lies at the heart of conceptual metaphor studies. By this, we mean, for instance, that all the potentially different source domains that can be used to conceptualize a particular abstract entity such as 'time' are, to a large extent, not only culturally bound, but also, and most importantly, the result of our own culturally-situated experiences in/with the world. Lakoff and Johnson (1980) pointed out that "the most fundamental values in a culture are coherent with the metaphoric structure of the most fundamental concepts in the culture" (p. 22). The fact that 'time' is conceptualized in terms of 'money' in the Anglo-Saxon world, and in terms of 'gold' in the Spanish-speaking world is certainly not the result of pure linguistic 'accidents'. On the contrary, it is a reflection of the different cultural models and schemas that frame our thinking, reasoning, and talking about the world.

The cultural value attached to metaphor is also evident in another participant's response which, unlike Peter's, stresses how our own individual 'cultures' sometimes help interpret the multiple shades of meaning that a single metaphor could carry.

Some metaphorical expressions can have different meanings, and you can think about them or be interpreted in different ways. They may have one meaning but our individual cultures, experiences and understanding lead to different interpretations, and sometimes this leads to miscommunication and misunderstanding

(Anne).

The cultural perspective from which Anne defines metaphor touches on our experientiallygrounded reasoning, which systematically shapes the way in which we make sense of the world, as well as the way in which we talk about it. The cultural specificity dimension of metaphor in Anne's definition problematizes the process of meaning making and interpretation of metaphor, which, in her view, may cause communication problems. This is a perspective that advances traditional thinking and theorizing about metaphor. Kövecses (2005), for instance, argues that much of the growing interest in the relationship between metaphor and culture is, to a larger extent, the result of the dominant role of 'primary metaphors' which have occupied the attention of cognitive linguistics working on the universality of metaphor. This is partly implied in another participant's view:

I believe metaphors are in all languages as they help us express our feelings, our thoughts, our identity, and I think we can understand them without no problem, maybe if you translate it from one language to another the metaphors should be the same, but not in all societies (Pamela)

Perhaps, Pamela has not come to the realization that metaphor is much more than translatable lexical chunks from one language to another. Although no explicit mention is made about the cultural variation of metaphor in Pamela's observation about metaphor, it is indicated that, irrespective of the apparent similarity of metaphor across languages, there can be differences in different 'societies'.

What becomes clear across the teachers' remarks and observations about metaphor is the strong emphasis on culture. There is, however, a tendency towards associating metaphor, and its cultural dimension, with the teaching and learning of idiomatic expressions, thus relegating the pervasively complex nature of metaphor to lexicon. The source of this limited perspective on metaphor was explored through questions about their 
readiness, their preparation, and the challenges to deal pedagogically with metaphor, which is reported in the next section.

\section{In need of preparation}

A common observation made by all teachers when asked about challenges faced in implementing a teaching approach to metaphor concerns the lack of teacher preparation at the university. In fact, one participant explicitly stated that no reference whatsoever was made to methodological approaches or strategies that could be used in the teaching of metaphor during their teacher training:

I never really heard of metaphor teaching when I was doing my degree. There was always a lot of emphasis on communicative methodologies, and fun and meaningful activities, and even on trying to bring culture to the classroom but never related to metaphor which is really important in culture but not covered (Sharon).

Sharon's confession about never hearing of 'metaphor teaching' during the course of her degree ratifies not only the heavy reliance of English teacher education programs on the so-called 'communicative methodologies', but also a certain level of failure to accurately interpret the premises of these methodologies, since metaphor lies at the heart of communication.

Of interest is to note that despite the 'specialized knowledge' that teachers develop throughout the program, no reference whatsoever seems to be made to the interplay of metaphor and culture.

Most of our training is really a lot about having a good understanding of grammar, phonetics, and teaching methodology, which is really good. We have a lot of grammar courses, phonetics and some teaching methodology, but nothing really about cross-cultural studies, like understanding how people in different cultures, like Spanish and English, communicate, how they see the world, how we use language in different ways. It's a big gap in the curriculum that should be different (Peter).
The systematically solid preparation and overreliance on the domains of grammar, phonetics, and teaching methodology are greatly valued by Peter. Nevertheless, he touches on the cultural dimension of language which, in his view, does not appear to be explored in teacher education programs. Peter's allusion to 'cross-cultural studies', people's diverse cultural conceptualizations and worldviews, along with different uses of language, appears to be leading into a perceived relationship of metaphor and culture. Without delving into the conceptual differences or subtleties around such terms as 'intercultural communication', 'cross-cultural communication', and 'intracultural communication' (Dervin et al., 2011; Matsumoto, 2000), what is important to stress is that any attempt at successful communication with speakers of other language backgrounds requires understanding of their diverse social-cultural practices, various forms of interaction, their identity formation (Norton and De Costa, 2018), and their worldviews (Ting-Toomey, 1999). It would seem that, through pre-service teacher education programs that address the sociocultural domain of language with a particular focus on metaphor, it would be possible to not only help bridge the gaps in the current curriculum, but also facilitate greater depth and breadth of knowledge of other cultures which might lead to 'best practices' in teaching.

I believe that if we had had a more consistent
course or workshop on understanding the role of
figurative language in reading, writing, different
kinds of texts, and in the way we talk every day,
we would be more prepared, and with more skills
to understand all aspects about English but also
different English cultures, and this would help
us to teach better and to help our students to
understand how English people think (Anne).

Anne's recognition of the potential benefits of more systematic preparation to deal with metaphor in language teaching leads her to believe that a broader understanding of various cultural aspects of English can be gained, which, as a consequence, can be facilitative of more effective teaching practices. This is of particular interest, as it reveals what it means for Anne to deliver English language teaching that is meaningful and relevant to learners. 
The need for pedagogical preparation to embed the significance of metaphor in language teaching is evident in the teachers' observations. What is particularly striking about the findings in this section is not only that pre-service teachers do not appear to be pedagogically ready to deal with metaphor in language teaching, but also that its potential integration in teacher education programs could bring about positive changes to both teachers' pedagogies and learners' broader cultural understandings and uses of language.

\section{A different teaching 'culture', a different focus}

A fundamentally important and profoundly revealing pattern emerging from the data concerns the teachers' firm belief that, despite the lack of pedagogical preparation and the opportunities they sought for improvement, a rather dominant factor that obscures effective pedagogies for metaphor teaching is the strong culture of compliance in many schools. This is what is alluded to in the observation made by Peter:

If I had the skills and methodology to teach a metaphor approach, or even the opportunities to improve my skills like workshops, I am sure I would be able to do it very well, but the context of my school would not really allow for it because we have to give the students too many tests, lots of meetings, so we don't have time for innovation in teaching (Peter).

Despite the confidence and great sense of self-assurance that Peter displays in relation to the delivery of a metaphor approach, had he had the adequate preparation, it appears that any attempt at innovation in teaching is likely to be hampered by not only what could be unnecessary 'over-governance', but also by clear signs of an accountability approach through a strong culture of testing. We all know that measurement of educational outcomes in the form of testing and assessment is deemed important on various levels. Nevertheless, when testing practices have been unwittingly conducted to the detriment of teaching and learning, and not specifically directed at helping learners achieve specific learning outcomes, teachers' professional knowledge and capabilities appear to be threatened due to an excessively unnecessary focus on teaching to tests, as reported in the following comment:

The teaching culture should change, it's not just about pedagogy courses, or short courses here and there, which we have access to sometimes, and it has to change for us to be able to innovate in teaching. For me, this idea of metaphor, and teaching metaphor is new, and I would like to try it but there are so many tests in a semester, almost one every two weeks that you really have to focus on preparing them for the test (Pamela).

In discussing some of the consequences of all forms of testing, Stobart and Eggen (2012) argue that the main negative impact of testing - and particularly of high-stakes testing - on teaching and learning is on how easily it becomes "focused on drilling for the tests" (p. 3). This, according to Pamela, seems to be one of the major impediments to teaching innovation through the novelty of a metaphor approach. A way of alleviating many, if not all, of the effects of a strong testing culture is by seeking opportunities for a paradigm shift in the EFL teaching in Chile, through which a renewed anatomy of teaching and learning can be explored. This was, to a large extent, hinted at in Sharon's comment:

If we really, really wanted to try something different, like more communication activities, teaching vocabulary and metaphor, using more games in class, we would need to be more actively involved in deciding how we implement the curriculum in the school because we basically have to do what the curriculum says and what the principal wants. I think a focus on metaphor as existing in every aspect of life can help focus on more real communication (Sharon).

A good grasp of metaphor in another language adds benefits to the learner's social, cultural and linguistic repertoire (Littlemore, 2001, 2009). Some scholars (e.g. Charteris-Black, 2002; Danesi, 1990, Littlemore and Low, 2006; O'Reilly \& Marsden, 2019) have suggested that the traditional model of communicative competence (Hymes, 1972) needs rethinking so as to incorporate a dimension that 
addresses people's ability to use and understand metaphor in different social situations, a dimension which has been termed 'metaphoric competence'. What appears to be quite evident in Sharon's reflection is that a more flexible, participatory approach to curriculum implementation is critical to introducing pedagogical changes that allow for the development of learners' communicative skills. Central to this is 'the capacity of a curriculum to be adjustable' to the individual needs of learners and those of the context within which it is being implemented. What becomes particularly salient in Sharon's observation is that "a focus on metaphor" as being pervasive in "every aspect of life" seems to be a channel through which learners' communicative skills can be enhanced. Hence, a different degree of trust in teachers is indicated.

It has become clear from the teachers' responses that a major impediment to enacting a metaphor approach that allows for the development of learners' communicative language skills is, besides their lack of preparedness, as indicated earlier, a rigid mandated curriculum and a highstakes accountability system that limits teachers' capabilities to get actively involved in decisionmaking processes in schools.

\section{Discussion}

The first theme, Metaphor in language and culture vividly captures teachers' perceptions of the interplay between metaphor and its role, significance, and position in language and culture. Unlike the traditional views on metaphor, contemporary metaphor research acknowledges their complex conceptual structure and their reliance on cultural-historical activity (Glebkin, 2013). The level of unanimity amongst teachers on the intricate relationship between (metaphorical) language and culture was evident in their responses.

It is worth noting that a rather salient element that permeated through teachers' responses concerned their views about metaphor as being an essential aspect of human cognition. According to Khajeh and Abdullah (2012) "metaphor conceptualizations are projections of conceptual structures which reside in speakers' cognition in a manner that enables them to comprehend certain abstract experiences in terms of more concrete ones" ( $p$. $70)$. This view, which stands in stark contrast with traditional understandings of metaphor as being particularly linked to literary and poetic studies, confirms that metaphor is no longer viewed as a linguistic ornament, but a conceptual device that allows us to think and speak about abstract entities in terms relating to more concrete ones (Lakoff and Johnson, 1980; Evans, 2006). Although teachers did not elaborate extensively on the cognitive dimension of metaphor, there was clear allusion to metaphor as being 'ways of thinking' which, according to teachers, are situated in everyday social and cultural practices.

Teachers' comments on metaphor evidenced a particular inclination towards their cultural significance in daily lives, and more specifically in relation to their first language. Several of them pointed out that 'every time they think of metaphor, what comes to mind is Spanish idioms'. What this appears to suggest is that, although much is yet to be done in teacher education programs in terms of preparation for metaphor teaching, their early and primary interactions and experiences with the world have contributed significantly to their current cultural understandings of metaphor. This is what drives of the conceptual framework of contemporary reasoning and philosophizing about metaphor, wherein the metaphorical patterning of our conceptual structures is grounded in our primary, sensorimotor experiences with the world (Evans, 2003).

It is clear that, although teachers' views and understandings of metaphor are not significantly distinct from how it is defined by, for instance, CL, their commentaries alluded unanimously to a lack of explicit and systematic preparation for 'metaphor pedagogy' in teacher education programs. This means that, despite their sound understanding of metaphor and how it relates to and permeates through culture, they do not possess the teaching or methodological skills, knowledge, or strategies to be able to implement a metaphor approach in their EFL teaching practices. Their comments implied that, in order for them to embed cultural elements 
of metaphor into the teaching of various language skills, changes to the curriculum at teacher training level must be made. It was acknowledged that what has overshadowed any possible attempt to integrate a metaphor teaching approach into (teacher education) curricula and educators' teaching practices is the strong impetus for developing teachers' content and subject knowledge, particularly in the areas of grammar and phonetics. As much as this is valued by teachers, a clear gap in the curriculum is what one of the teachers refers to as 'cross-cultural studies' or anything along those lines that allows them to understand "how people see the world, and how they use language differently" (Peter).

As much as the readiness to implement a metaphor approach in an EFL classroom impinges heavily on the training and preparation in teacher education programs, teachers also commented that 'workshops' and 'professional development' sessions would greatly assist in the integration of culturally-bound aspects of language such as metaphor into the teaching of language skills. Nevertheless, these opportunities to upskill or improve their practice cannot be fully leveraged due to a pervasively strong culture of compliance, accountability, and performativity that permeates through most aspects of teaching and learning. This manifests itself particularly in the volume of low and high-stakes testing, which consumes teachers' valuable time that could be used to innovate in the EFL classroom, as some of the participants observed. Where tests are used for accountability purposes (Stobart and Eggen, 2012), a situation that becomes palpable across the globe, it is easy to observe high levels of tight control and governance within schools that not only reduce the chances for flexibility and innovation in the EFL classroom, but also disempower teachers to a level where their decision-making power to adjust the curriculum to the demands of the context and needs of the students become increasingly minimal. Should changes occur at teacher training levels and at the level of pedagogical implementation in EFL contexts for an approach that allows for the teachability of metaphor, a more reasonably well-balanced curriculum would need to be enacted. By this, we mean one that fosters the sound development of EFL teachers' 'specialist knowledge' of the subject matter, but also a curriculum that provides sufficient opportunities for cross-cultural studies which could potentially help teachers develop a deeper understanding of how metaphor works and functions across languages.

\section{Conclusion}

Despite the great volume of metaphor research that has been produced in the last few decades, there are yet significant strides to be made in research about the applications and implications of metaphor for language pedagogy. The findings of this study have revealed that, despite teachers' reasonably good understanding of the ubiquity of metaphor, as well as of its role in and relationship with culture, their pedagogical knowledge and capabilities need significant and deliberate development and training. As reported by the teachers, a great deal of emphasis continues to be placed upon teachers' readiness to teach grammar, along with other formal aspects of language such as phonetics and phonology. This seems to relegate other fundamentally important layers of language to a less important place. Gutiérrez-Pérez (2016) pointed out that, through effective teaching of conceptual metaphor, learners can successfully come to an appreciation and better understanding of register shifts in conversation, connotative levels of meaning, and sociolinguistic appropriateness. If this were hoped to be achieved in EFL teaching in Chilean classrooms, significant changes at various levels would need to occur. First and foremost, the reported data suggests that existing gaps in English language teacher education programs must be addressed to such extent that theoretical, pedagogical, and methodological balance is achieved and sustained in the preparation of pre-service teachers. This means that, as much as attention is given to pre-service teachers' preparedness and readiness to teach the formal aspects of language, attention must also be paid to equipping them with the professional knowledge to help students develop socio-cultural and sociolinguistic skills to use and comprehend the English language more effectively in the context of other English speakers. 
The realization and potential feasibility of the above is, however, dependent upon changes to the macro structures and highly politicized systems that frame teaching and learning pedagogies in Chile. By this we mean modifications to the underlying principles that govern the English curriculum in Chile to an extent that a broader socio-cultural perspective on language is adopted. This could be facilitative of pedagogies that not only address the formal mechanics of language but also of the various universally- and culturally-bound processes through which meaning is constructed, of which metaphor, in its multiple forms, is probably one of the most salient in language.

\section{References}

Agencia de la Calidad de la Educación (2020). Categoría de desempeño. https://www.agenciaeducacion.cl/ evaluaciones/categoria-de-desempeno/.

Arsen, D., \& Mason, M. (2013). Seeking accountability through State-appointed emergency district management. Educational Policy, 27(2), 248-278. https://doi.org/10.1177/0895904813475711

Avalos, B. (2004). Teacher regulatory forces and accountability policies in Chile: from public servants to accountable professionals. Research Papers in Education, 19(1), 67-85. https://doi. org/10.1080/0267152032000179981

Avalos, B., E Assael, J. (2006). Moving from resistance to agreement: The case of the Chilean teacher performance evaluation. International Journal of Educational Research, 45(4-5), 231-324. https://doi. org/10.1016/j.ijer.2007.02.004

Aviles, E., \& Simons, M. (2013). To be accountable in Neoliberal times: an exploration of educational policy in Ecuador. Policy Futures in Education, 11(1), 1-12. https://doi.org/10.2304/pfie.2013.11.1.1

Barber, M., \& Mourshed, M. (2018). Cómo hicieron los sistemas educativos con mejor desempeño del mundo para alcanzar sus objetivos. http://www.oei. es/pdfs/documento preal41.pdf

Braun, V., \& Clarke, V. (2006). Using thematic analysis in Psychology. Qualitative Research in Psychology, 3(2), 77-101. http://10.1191/1478088706qp063oa.

Canale, M., E Swain, M. (1980). Theoretical bases of communicative approaches to second language teaching and testing. Applied Linguistics, 1(1), 1-47. https://doi.org/10.1093/applin/I.1.1
Charteris-Black, J. (2002). Second language figurative proficiency: A comparative study of Malay and English. Applied Linguistics, 23(1), 104-133. https:// doi.org/10.1093/applin/23.1.104

Danesi, M. (1986). The role of metaphor in second language pedagogy. Rassegna Italiana di Linguistica Applicata, 18(3), 1-10.

Danesi, M. (1990). Thinking is seeing: visual metaphors and the nature of abstract thought. Semiotica, 80(3-4), 221-237. https://doi.org/10.1515/ semi.1990.80.3-4.221

Deignan, A., Gabrys, D., \& Solska, A. (1997). Teaching English metaphors using cross-linguistic awareness raising activities. ELT Journal, 51, 352-360. https:// doi.org/10.1093/elt/51.4.352

Dervin, F., Gajardo, A., E Lavanchy, A. (Eds.). (2011). Politics of interculturality. Cambridge Scholars Publishing.

Dirven, R. (1985). Metaphor as a basic means for extending the lexicon. In W. Paprotte $\mathcal{E}$ R. Dirven (eds): The Ubiquity of Metaphor (pp. 85-119). John Benjamins.

Dirven, R., \& Vespoor, M. (2004). Cognitive explorations of language and linguistics. John Benjamins. https:// doi.org/10.1075/clip.1

Doecke, B., Kostogriz, A., \& Charles, C. (2004). Heteroglossia: a space for developing critical language awareness? English Teaching: Practice and Critique, 3(3), 29-42.

Evans, V. (2003). The Structure of Time: Language, Meaning and Temporal Cognition. John Benjamins. https://doi.org/10.1075/hcp.12

Evans, V., \& Green, M. (2006). Cognitive linguistics: An introduction. Edinburgh University Press.

Fan, T. P. C., \& Tan, A. T. L. (2015). How product attributes influence internationalization: A framework of domain-and culture-specificity. Management International Review, 55(1), 53-76. https://doi. org/10.1007/s11575-014-0229-0

Farías, M., E Véliz, L. (2016). EFL students' metaphorical conceptualizations of language learning. Trabalhos de Linguistica Aplicada, 55(3), 833-850. https://doi. org/10.1590/010318135146185751

Farías, M., \& Véliz, L. (2019). Multimodal texts in Chilean English teaching education: Experiences from educators and pre-service teachers. Profile: Issues in Teachers' Professional Development, 21(2), 13-27. https://doi.org/10.15446/profile.v21n2.75172

Fernández, B. (2018). Framing teacher education: Conceptions of teaching, teacher education, and justice in Chilean National policies. Education 
Policy Analysis Archives, 26(34), 1-37. https://doi. org/10.14507/epaa.26.2806

Glebkin, V. (2013). A socio-cultural history of the machine metaphor. Review of Cognitive Linguistics, 11(1), 145-162. https://doi.org/ 10.1075/rcl.11.1.04.gle

Goddard, C., \& Wierzbicka, A. (2007). Semantic primes and cultural scripts in language learning and intercultural. Applied Cultural Linguistics: Implications for second language learning and intercultural communication, 7(1), 105-124. https:// doi.org/ 10.1075/celcr.7.08god

Graves, K. (2008). The language curriculum: A social contextual perspective. Language Teaching, 41(2), 147-181. https://doi.org/10.1017/ $\underline{\text { S0261444807004867 }}$

Gutiérrez-Pérez, R. (2016). Teaching conceptual metaphors to EFL learners in the European space of higher education. European Journal of Applied Linguistics, 5(1). https://doi.org/10.1515/ eujal-2015-0036

Hoang, H. (2014). Metaphor and Second Language Learning: The State of the Field. The Electronic Journal for English as a Second Language, 18(2). http://www.tesl-ej.org/wordpress/issues/volume18/ ej70/ej70a5/

Hsiao, H. S., \& Leong, O. K. (2018). Effect of metaphor awareness on L2 vocabulary learning and retention. Chinese as a Second Language Research, 7(1), 141-170 h t t p s : // d o i . org/10.1515/eujal-2015-0036

Hymes, D. (1972). On communicative competence. In J. B. Prides \& J. Holmes (Eds.). Sociolinguistics: selected readings (pp. 269-293). Penguin.

Johnson, B., \& Onwuegbuzie, A. (2004). Mixed methods research: A research paradigm whose time has come. Educational Researcher, 33(7), 14-26. https:// doi.org/ 10.3102/0013189X033007014

Kalyuga, M., \& Kalyuga, S. (2008). Metaphor awareness in teaching vocabulary. Language Learning Journal, 36(2), 249-257. https://doi. org/10.1080/09571730802390767

Khajeh, Z., \& Abdullah, I. (2012). Persian culinary metaphors: A cross-cultural conceptualization. Gema Online Journal of Language Studies, 12(1), 69-87. http://journalarticle.ukm.my/3264/

Kövecses, Z. (2005). Metaphor in culture: universality and variation. Cambridge University Press. https:// doi.org/10.1017/CBO9780511614408

Lakoff, G., E Johnson, M. (1980). Metaphors We Live By. University of Chicago Press. https://10.7208/ chicago/9780226470993.001.0001
Laufer, B. (2006). Comparing focus on form and focus on formS in second-language vocabulary learning. The Canadian Modern Language Review, 63(1), 149166. https://doi: 10.3138/cmlr.63.1.149

Littlemore, J. (2001). Metaphoric competence: A language learning strength of students with a holistic cognitive style? TESOL Quarterly, 35(3), 459-491. https://doi. org/ 10.2307/3588031

Littlemore, J. (2005). Figurative thought and the teaching of languages for specific purposes. Proceedings from the VIII Jornadas de lenguas para fines especificados, Universidad de Alcalá, Spain, pp. 16-34.

Littlemore, J., \& Low, G. (2006). Metaphoric Competence, Second Language Learning, and Communicative Language Ability. Applied Linguistics, 27(2), 268294. https://doi.org/10.1093/applin/aml004

Littlemore, J. (2009). Applying cognitive linguistics to second language learning and teaching. Palgrave Macmillan.

Littlemore, J. (2010). Metaphoric competence in the first and second language. Converging evidence in language and communication research (CELCR), 13, 293. https://doi.org/ 10.1075/celcr.13.20lit

Matsumoto, D. (2000). Cross-cultural communication. In A. Kazdin (Ed.). Encyclopedia of Psychology (pp. 357-359). American Psychological Association.

Newton, P., Driver, R., \& Osborne, J. (1999). The place of argumentation in the pedagogy of school science. International Journal of Science Education, 21(5), 553-576. https://doi.org/10.1080/095006999290570

Norton, B., \& De Costa, P. I. (2018). Research tasks on identity in language learning and teaching. Language Teaching, 51(1), 90-112. https://doi.org/ 10.1017/ $\underline{\text { S0261444817000325 }}$

O'Reilly, D., \& Marsden, E. (2019). Eliciting and Measuring L2 Metaphoric Competence: Three decades on from low (1988). Applied Linguistics. https://doi. org/10.1093/applin/amzn066

Peeters, B. (Ed.). (2006). Semantic primes and universal grammar: Empirical evidence from the Romance languages. John Benjamins Publishing. https://doi. org/10.1075/slcs.81

Peters, M. (2012). Neoliberalism, education and the crisis of Western capitalism. Policy Futures in Education, 10(2), 134-141. https://doi.org/10.2304/ pfie.2012.10.2.134

Picken, J. (2005). Helping foreign language learners to make sense of literature with metaphor awarenessraising. Language Awareness, 14(2-3), 142-152. https://doi.org/10.1080/09658410508668830 
Shen-Feng, G. (2007). Is Idiom Comprehension Influenced by Metaphor Awareness of the Learners? A Case Study of Chinese EFL Learners. Linguistics Journal, 2(3), 148-166.

Srivastava, P., \& Hopwood, N. (2009). A practical iterative framework for qualitative data analysis. International JournalofQualitativeMethods, 8(1), 7684. https://doi.org/10.1177/160940690900800107

Stobart, G., \& Eggen, T. (2012). High-stakes testing: value, fairness, and consequences. Assessment in Education: Principles, Policy and Practice, 19(1), 1-6. https://doi. org/10.1080/0969594X.2012.639191

Ting-Toomey, S. (1999). Communicating across cultures. Guilford Press. https://10.4236/ad.2014.22003

Tyler, A. (2012). Cognitive Linguistics and Second Language Learning: Theoretical Basics and Experimental Evidence. Routledge. https://10.4324/9780203876039

Véliz, L. (2018). A route to the teaching of polysemous lexicon: benefits from cognitive linguistics and conceptual metaphor theory. International Journal of Applied Linguistics and English Literature, 7(1), 211217. https://doi.org/10.7575/aiac.ijalel.v.7n.1p.211

Véliz, L. (2016). Enhancing ESL learners' vocabulary learning of metaphorically-used words. Journal of Language Teaching and Research, 8(5), 835-846. http://dx.doi.org/10.17507/jltr.0805.01

Wang, D., Moloney, R., \& Li, Z. (2013). Towards internationalising the curriculum: A case study of Chinese language teacher education programs in China and Australia. Australian Journal of Teacher Education, 38(9), 116-135. http://dx.doi. org/10.14221/ajte.2013v38n9.8 